\title{
The occurrence of persistent chlorinated and brominated organic contaminants in the European eel (Anguilla anguilla) in Irish waters.
}

\author{
Brendan McHugh ${ }^{\mathrm{a}^{*}}$, Russell Poole ${ }^{\mathrm{b}}, \mathrm{John}_{\text {Corcoran }}^{\mathrm{c}}$, Pinelopi Anninou ${ }^{\mathrm{a}}$, Brian Boyle, \\ Eileen Joyce ${ }^{\mathrm{a}}$, M. Barry Foley ${ }^{\mathrm{d}}$ and Evin McGovern ${ }^{\mathrm{a}}$.
}

\footnotetext{
${ }^{a}$ Marine Institute, Rinville, Oranmore, Galway, Ireland

${ }^{\mathrm{b}}$ Marine Institute, Furnace, Newport, Co. Mayo, Ireland

${ }^{c}$ Department of Zoology, Trinity College Dublin, Ireland

${ }^{d}$ School of Chemical and Pharmaceutical Sciences, Dublin Institute of Technology, Kevin St., Dublin 2.
}

*Corresponding Author: Brendan McHugh, Marine Institute, Rinville, Oranmore, Galway, Ireland. Tel :+353 91387 200, Fax:+353 $91387201 .{ }^{1}$ email: Brendan.mchugh@marine.ie

\footnotetext{
*Corresponding Author: Brendan McHugh, Marine Institute, Rinville, Oranmore, Galway, Ireland. Tel :+35391387 200, Fax:+35391387 201. email: Brendan.mchugh@marine.ie
} 


\begin{abstract}
The European eel (Anguilla anguilla) is a relatively high lipid, long lived species capable of living in a variety of brackish, fresh and marine habitats. As such, eels can accumulate organic pollutants and have been incorporated into environmental monitoring programs as a suitable "bioindicator" species for the determination of the levels of organic contaminants within different water bodies. The global eel stock is now in decline and while the cause of the collapse remains unidentified, it is likely to include a combination of anthropogenic mortality in addition to environmental degradation. This study provides valuable data on a range of contaminants (PCDD/Fs, PCBs, OCPs, PBDEs, HBCD, TBBPA and PBBs) and extractable lipid levels in eel muscle tissue collected from five Irish catchments. Extractable lipid levels were lower in the yellow eels compared to those in the silver eels. These levels were similar to those reported elsewhere and it has been posited that a decline in the lipid content in yellow eels may have consequences for the future viability of the stock. With the exception of higher substituted dioxins (especially OCDD), in 3 samples collected from one catchment (Burrishoole) in the West of Ireland, POP levels in general were determined to be low in eels from Irish waters compared to those in other countries.
\end{abstract}

Keywords: European eel, lipid, PCDD/F, flame retardants, organic persistent pollutants, food safety. 


\section{Introduction}

Throughout Europe the numbers of glass eels (Anguilla anguilla) returning from sea has declined since the early 1980s and the stocks have declined in most of the distributional area and are considered below safe biological limits (Bertin, 1956; Feunteun, 2002; Dekker, 2003; Tesch, 2003). The International Council for the Exploration of the Sea (ICES, 2006) suggested that spawner quality issues (i.e. parasites, disease, contaminants) are highly likely to impact on migration and spawning success, however a lack of reliable data over the wide geographical range of the eel makes it difficult to assess the impact of these issues on the global spawning stock of European Eel. While the cause of the eel stock collapse remains unidentified, it is likely to include a combination of anthropogenic mortality (e.g. fishing \& turbines) in addition to environmental degradation. It is additionally suggested that accumulation of contaminants and/or a reduction in energy reserves (lipid levels) may be impairing the quality of potential spawners (Belpaire et al., 2009).

It is well documented that the eel progresses through five principal life cycle stages namely, the leptocephalus, glass eel, elver, yellow and silver eel stages (de Boer et al., 1994). The leptocephali metamorphose into glass eels and a proportion migrate upstream as elvers. At the latter stages elvers develop into the yellow eel stage, which continue to feed and grow in a wide range of habitats in marine and freshwater, before completing their life cycle and metamorphosing to the silver eel stage for migration to the spawning grounds of the Sargasso Sea (Bertin, 1956; Tesch, 2003). This ability for eels to inhabit such a diverse range of marine and freshwater environments, along with a wide variety of 
dietary influences, may subject eels to multiple routes (sources) of exposure to environmental contaminants Eels spend a large proportion of their lives in estuarine and/or freshwater systems which when combined with their long lifecycle and diverse feeding patterns can result in the eel accumulating substantial body burdens of environmental pollutants (Versonnen et al., 2004; de Boer et al 1994).

Dioxins (PCDDs), furans (PCDFs) and polychlorinated biphenyls (PCBs) are reported to be toxic and bioaccumulative, and thus potentially pose a major health risk to the consumer of seafood and possibly to the eels themselves (Ryan et al., 1990; Giesy and Kannan, 1998; van den Berg et al., 2006). The most toxic dioxin congener is 2, 3, 7, 8tetrachlorodibenzo-p-dioxin (2, 3, 7, 8-TCDD). Particular concern is expressed about the 12 so-called non-ortho (PCBs 77, 81, 126, 169) and mono-ortho (PCBs 105, 114, 118, $123,156,157,167,189)$ dioxin-like (DL) PCBs, for which essentially the toxic effects are based on the same principle as that of PCDDs and PCDFs, since they also bind to the aryl hydroxyl (Ah) receptor. Other PCBs are known as non-dioxin-like (NDL) PCBs and they do not exert their toxicological effects via binding to the Ah receptor but nonetheless are associated with a wide spectrum of toxic responses (Legare (2000); Giesy and Kannan, 1998).

Brominated flame retardants (BFRs) comprise a group of chemicals, which are added to many household products for the purpose of fire prevention. Limited toxicity (and often environmental prevalence) data are available for polybrominated diphenyl ethers (PBDEs), hexabromocyclododecane (HBCD), polybrominated biphenyl (PBB) and 
tetrabromobisphenol-A (TBBPA). The potential of these chemicals to cause toxic effects though has been documented (Meironyte et al., 1999; de Boer et al., 2000; Spiegelstein, 2000; Kitamura et al., 2002; Alaee et al., 2003; Vos et al., 2003; Birnbaum and Staskal, 2004). Based on their lipophilic nature, environmental persistence and bioaccumulation potential, chlorinated pesticides (OCPs) represent a threat to aquatic organisms a number having been linked to many health problems in marine mammals (Reijnders, 1986; Reijnders, 1994; de Swart et al., 1994).

\subsection{Summary contaminant related effects and legislation.}

There are currently no EU maximum limits for BFRs in food and tolerable daily intakes (TDIs) have not been derived, primarily due to limited toxicological data and the associated uncertainties with such studies. EFSA currently recommends the monitoring of BDE 28, 47, 99, 100, 153, 154, 183 and 209, in addition to PBB153 and HBCD in foods and feeds (European Food Safety Authority, 2006). With the exception of PBDE209 all of these compounds were analysed in this study.

No legislation exists restricting the production of TBBPA or its derivatives and it is placed on the fourth list of priority chemicals under European Council (EC) Regulation No. 793 regarding the evaluation and control of the risks of existing substances (European Commission, 2000). Due to its high production volumes TBBPA will however be one of the first substances to go through the EU REACH (registration, evaluation, authorisation and restriction of chemicals) registration process (European Commission, 2006a) and as such monitoring data are of importance. 
There are currently no maximum levels for NDL-PCBs set by the EC, however, a number of Member-States have set national levels for individual or sum of 7 indicator/marker PCBs. A stringent level has been set in Belgium for the sum of 7 indicator PCBs with a maximum level of $75 \mu \mathrm{g} \mathrm{kg}^{-1}$ product for "Fish, including shellfish, crustaceans and foodstuffs derived thereof" (EU Working Document, 2005). The European Commission is currently considering the regulation of NDL-PCBs, possibly via setting maximum levels for 6 indicator PCBs (28, 52, 101, 138, 153 and 180).

EFSA report that no health based guidance value for humans can be established for NDLPCBs because simultaneous exposure to NDL-PCB and DL-compounds hampers the interpretation of the results of the toxicological and epidemiological studies, and the database on effects of individual NDL-PCB congeners is rather limited (European Food Safety Association, 2003). There are, however, indications that subtle developmental effects, being caused by NDL-PCB, DL-PCB, or PCDD/Fs alone, or in combination, may occur at maternal body burdens that are only slightly higher than those expected from the average daily intake in European countries (EFSA, 2005). Because some individuals and some European (sub)-populations may be exposed to considerably higher average intakes, EFSA report that a continued effort to lower the levels of NDL-PCB in food is warranted.

As part of its exposure reduction strategy the EC has also introduced maximum levels for PCDDs, PCDFs and DL-PCBs in foodstuffs, via Council Regulation (EC) No. 
1881/2006; this sets maximum levels for certain contaminants in foodstuffs (European Commission, 2006b). The maximum level established for the sum of PCDD/Fs in eel

muscle is currently $4 \mathrm{pg} \mathrm{g}^{-1}$ WHO-PCDD/F-TEQ (toxic equivalents) whole weight and 12 $\mathrm{pg} \mathrm{g}^{-1}$ WHO-PCDD/F-PCB-TEQ whole weight for the sum of PCDD/F and DL-PCBs. Toxic equivalency factors (TEFs) are additionally available for fish and wildlife (table 2) however their application to address the significance of potential and/or existing exposure to DL-compounds can be subject to a number of limitations (Tillett, 1999). As TEFs (van den Berg et al., 2006) for PCDD/Fs and DL-PCBs have not been adopted in EC legislation to date they have not been utilised in this report.

Relatively few data documenting contaminant levels in eels from Irish waters are available, as such, levels of extractable lipid, PCDD/Fs, PCBs, OCPs, PBDEs, HBCD, TBBPA and PBBs in eel muscle tissue are reported.

\section{Experimental.}

Between October and November 2005 eels were obtained at an initial 5 separate river systems throughout Ireland from commercial fishermen or from fish monitoring traps in the case of those from the Burrishoole catchment (Figure 1). Primarily on the basis of dioxin profiling in these initial samples, a second sampling event was completed in the Burrishoole (silver eel) and L. Feeagh (from where the majority of Burrishoole silver eel originate) area in 2007 where 2 additional samples were collected. Sampling details are presented in table 1 and figure 1. 


\subsection{Sampling methodology - eel biology}

At each site at least 210 eels were randomly selected from each commercial catch or from the traps at Burrishoole (Poole et al., 1990). Commercial eels were captured either by coghill/fyke net (mesh size 8-10 mm bar) or with the use of eel-pots in tidal waters. 100 eels were immediately anaesthetised, with chlorobutanol, measured $( \pm 0.1 \mathrm{~cm})$ and frozen $\left(<-18{ }^{\circ} \mathrm{C}\right)$ for further biological examination and for subsequent removal of otoliths for ageing purposes. The remaining eels were also anaesthetised, measured for the purposes of estimating eel size distributions, then revived in freshwater before being returned alive to the water. 10 random eels, which were not subjected to anaesthetic, were individually bagged and frozen for contaminant analysis. Eels were sexed macroscopically by dissection and ageing analysis was carried out utilising otoliths prepared by burning and cracking (Moriarty, 1983; Poole and Reynolds, 1996), followed by reading under x100 magnification by two independent readers. Where discrepancies were reported, a third reading was taken and all three readings were then averaged.

2007 confirmatory sampling was completed in Burrishoole with the capture of 15 yellow eels from a fyke net survey catch of 106 eels on L. Feeagh and 12 silver eels from the traps. These samples were treated in a similar fashion to those taken in 2005.

\subsection{Sampling methodology - sub-sampling}

Pooled mixed sex samples of eel muscle were removed from between the pectoral fin and tail. Subcutaneous lipid was removed from skin and returned to the sample muscle tissue; 
9 to 15 individual eels (table 1) were then pooled, samples homogenized, sub-sampled and stored at $<-18^{\circ} \mathrm{C}$ prior to analysis.

\subsection{Determination of lipid in eel muscle}

The Central Science Laboratory (CSL), York, England completed lipid determinations on the mixed sex pooled eel muscle samples via a Werner-Schmidt type method (based on British Standard BS:4401:Part 4 1970) to remove lipids including some bound lipid. ERGO-Eurofins completed lipid analysis of eel muscle by the exhaustive extraction of tissue with a mixture of cyclohexane: acetone 7:3. Lipid content was then derived gravimetrically. Both laboratories show continued successful completion in internationally recognised lipid determination proficiency studies underpinning lipid quality assurance.

\subsection{Muscle tissue contaminants analysis}

Muscle tissue samples from the initial survey were analysed for a range of contaminant suites (incl. PCDD/Fs, PCBs, OCPs, PBDEs, PBBs, TBBPA) by Eurofins/ERGO, ERGO Forschungsgesellschaft mbH, Hamburg Germany according to EN ISO 17025 accredited methods GfA QMA 504-191/203/205. For the analysis of brominated flame retardant compounds, a GfA-established GC/MS method was used. Total HBCD ( $\operatorname{sum}$ of $\alpha^{-}, \beta-, \gamma-$ diastereomers) analysis was completed by ERGO laboratories while individual diastereomer analysis was completed on two samples (MSC/05/1119 and MSC/05/1121) by CSL on a Waters (Hertsford, UK) Alliance 2695 LC system with a Waters Sunfire (C18) column, coupled to a Micromass (Manchester, UK) Quattro Ultima triple 
quadrupole MS in negative electrospray ionisation mode. PCDD/F analysis on the 2007 samples was completed by CSL.

\subsubsection{Brominated Flame Retardant analysis}

Tissue samples were Soxhlet extracted with n-hexane and extracts were further treated on an $\mathrm{H}_{2} \mathrm{SO}_{4} / \mathrm{SiO}_{2}$ clean-up column. PBDEs, PBBs, total $\mathrm{HBCD}$ and TBBPA were quantified by HRGC/HRMS by means of internal / external standards. Recoveries for PBDEs were of the order $83 \%$ to $135 \%$; PBB recoveries ranged from $60 \%$ to $100 \%$ while HBCD and TBPPA recoveries were lower ranging between $41 \%$ to $70 \%$ and $25 \%$ to $50 \%$ respectively. No correction for recoveries was performed.

2.4.2 PCDD/F, PCB and OCP analysis.

Marker-PCBs (PCB 28, 52, 101, 118, 138, 153, 180) and OCPs were determined by GC/MS on a DB-5 capillary column following soxhlet extraction and clean-up on an alumina/silica column. Two isotope masses were measured and quantification was completed using appropriate internal/external standard mixtures. WHO-PCBs were determined by GC/HRMS following sample extraction and clean-up on a carbon/glassfibre column. Quantification was completed by the use of internal/external standard mixtures. Recoveries ranged from 62 to $105 \%$ for non-ortho, 70 to $110 \%$ for mono-ortho and from 77 to $118 \%$ for the sum of seven ICES PCBs (marker PCBs) respectively.

\subsection{Toxic Equivalency calculation}


The WHO-ECEH (European Centre for Environment and Health of the World Health Organization) toxic equivalency factors (WHO-TEFs) for PCDD/F and PCBs (van den Berg et al., 1998), were utilised. Total toxicity equivalents were calculated for each sample (see table 2) by summing the contribution of PCDD/F homologues reported in table 2. A combination of appropriate certified and/or laboratory reference materials were analysed with samples during this study.

\section{Results and Discussion}

\subsection{Biological characteristics of sampled eels}

For the 2005 samples, variances in eel length $(\mathrm{cm})$ between the pooled individuals for contaminants analysis $(n=10)$ and corresponding biological sample population $(n \geq 210)$ were found to be homogeneous (student-t and F-test statistics) $(\mathrm{P}<0.05)$ for four of the five locations sampled (exception Burrishoole). Additionally the mean age (32.3 yrs) of pooled individuals in the Burrishoole sample is greater than the average age of eels from other sampling sites (16.0 to 19.8 yrs) (table 1$)$. These age data are typical of slow growing Irish eels and are similar to those reported elsewhere in the literature (Moriarty, 1988; Poole and Reynolds, 1996). In 2007, the L. Feeagh eel sample was not aged but a similar sample taken in 2001 had a mean age of 22 years and the silver eels sampled in Burrishoole in 2007 had a mean age of 25.1 years.

\subsection{Lipid Levels in eel muscle}

Extractable lipid percentages in the two mixed sex yellow eel samples (8.28 and 9.18\%) were lower than those observed in the mixed sex silver eels (range 14.3 to 20.9\%). 
Belpaire et al. (2009) report that a decrease in fat content in yellow eels may be an element in the stock decline raising serious concerns about the chances of the stock to recover and suggest that only large individuals, with high lipid content seem to be able to contribute to the spawning stock. Only one sample in this study of Irish eels had lipid levels above the assumed $20 \%$ benchmark minimum level required for normal migration and reproduction (Belpaire et al., 2009).

Belpaire et al. (2009) report a decadal drop in lipid stores in eels from the Netherlands and as such consider this as a general indicator for the health of the population. The authors suggest that the decrease in fat stores of the yellow eels has a negative impact on the migration and reproduction capacity in the silver eels and thus results in decreased recruitment. It should be noted that mixed sex pooled eel samples which were analysed in this current study, eels from this study show similar lipid percentages to those reported by Belpaire et al. (2009).

\subsection{PCDD/F and WHO-PCBs in eel muscle tissue}

Total upperbound PCDD/PCDF-TEQs in the range 0.21 to $0.29 \mathrm{pg} \mathrm{g}^{-1}$ total-TEQ wet weight (ww) (1.04 to $1.30 \mathrm{pg} \mathrm{g}^{-1}$ (ww) were calculated for four of the 2005 samples in this study, while in the Burrishoole an elevated PCDD/PCDF of $4.37 \mathrm{pg} \mathrm{g}^{-1}$ total-TEQ (ww) was determined in the 2005 sample with PCDD/PCDF pg g $\mathrm{g}^{-1}$ total-TEQ (ww) of 1.24 - 2.50 determined in the 2007 samples (table 2). In the 2005 and 2007 Burrishoole

samples, PCDDs (4.24 and 2.42 and 1.19 pg TEQ pg g $^{-1}$ ww) respectively, contribute the majority of the total PCDD/F TEQ in eels at this location, While similar PCDD- 
TEQ/PCDF-TEQ ratios (1.75-2.45) were calculated at each of the four sampling sites with low total TEQ, the PCDD-TEQ/PCDF-TEQ ratios of 33.0 (2005) and 31.1 and 26.6 (2007) calculated in eels from the Burrishoole catchment shows much more elevated PCDD levels in these eels strongly suggesting point source influences at this location.

OCDD was not detected in four of the five initial survey samples however concentration levels of $42.0 \mathrm{pg} \mathrm{g}^{-1}$ (ww) were detected in the initial sample from the Burrishoole catchment. The PCDD/PCDF ratios in confirmatory samples MSC/07/1133 and MSC/07/1134 respectively are very consistent with the PCDD/PCDF ratio determined in the original Burrishoole sample (MSC/05/1140).

OCDD belongs to the group of "super-hydrophobic" or "super-lipophilic" compounds and has a high bioaccumulation factor (Geyer et al., 2000). Geyer further reports that OCDD is often the most prevalent polychlorinated PCDD found in pentachlorophenol (PCP) a persistent halogenated compound, which has primarily been utilized in the timber processing industry. The authors are not aware of information related to the application of PCP or any other dioxin containing substance within the Burrishoole catchment and no point sources are clearly identifiable within the catchment. Confirmatory analysis is currently subject of a separate investigation.

Total upperbound PCDF-TEQ in all samples were low, ranging from 0.04 to $0.13 \mathrm{pg} \mathrm{g}^{-1}$ (ww). Concentrations and consequentially PCDF-TEQs in the Burrishoole being much less elevated than those observed for PCDDs. 
Regarding levels of WHO-PCBs, the non-ortho PCBs 77 and 81 were low (nd to 0.46 pg $\mathrm{g}^{-1} \mathrm{ww}$ ) in the seven samples. Concentrations of PCB 126 ranged from not detected to 6.3 $\operatorname{pg~}^{-1}(\mathrm{ww})$. PCB 118 was the most dominant mono-ortho PCB present with levels ranging from 230 to $2783 \mathrm{pg} \mathrm{g}^{-1}$ (ww). The total mono-ortho PCB burden ranged from 370 to $4351 \mathrm{pg} \mathrm{g}^{-1}$ (ww). The combined mono-ortho and non-ortho WHO-PCB TEQ ranged from 0.17 to 1.24 WHO TEQ $\mathrm{pg} \mathrm{g}^{-1}$ (ww) in the seven samples. These values are well below the current EU food legislative maximum level for WHO-PCBs in eel tissue.

Stachel et al. (2007) report eel WHO-PCDD/F-TEQ of between 0.48 to 22 in German caught eels and further report that DL-PCB TEQs (range from 8.5 to 59 WHO-TEQ pg g ${ }^{-}$ ${ }^{1}$ ww) exceeded those of the PCDD/Fs.

\subsection{Marker PCBs}

Levels of marker PCBs in this study ranged from 1.94 to $18.1 \mathrm{ng} \mathrm{g}^{-1}$ (ww) (13.7 to 197 $\mathrm{ng} \mathrm{g}^{-1}$ lipid weight (lw)) and are comparable to those reported by Santillo et al. (2005) for the $\Sigma 7$ PCBs (32 and $114 \mathrm{ng} \mathrm{g}^{-1}$ lipid weight, $\mathrm{n}=2$ ) in Irish samples from the Owengarve Stream and Lough Furnace (a brackish lake in the Burrishoole catchment) respectively. Concentrations of marker PCBs reported by Santillo et al. (2005) in Irish samples were amongst the lowest determined in eels collected in various European countries. Santillo et al. (2005) report marker PCB concentrations up to $1512 \mathrm{ng} \mathrm{g}^{-1}$ (ww) (9947 $\mathrm{ng} \mathrm{g}^{-1} \mathrm{lw}$ ) in a composite sample from the Netherlands. One further study by de Boer and Hagel. (1994) reported lipid normalized concentrations ranging from $274 \pm 176 \mathrm{ng} \mathrm{g}^{-1}$ to $14400 \pm 9700$ 
$\mathrm{ng} \mathrm{g}^{-1}$ (lw) in 142 samples from the Netherlands. The Flemish eel pollutant monitoring network (Geomans et al., 2003) reported a mean PCB153 level of $166 \mathrm{ng} \mathrm{g}^{-1}$ (ww) in eels from Flanders (1994 to 2001). Maes et al. (2007) reported a mean concentration of 212 $\mathrm{ng} \mathrm{g}^{-1}$ (ww) in eels from Flanders (1994 to 2005). PCB153 concentrations of $18.6 \mathrm{ng} \mathrm{g}^{-1}$ (ww) have been reported in eels from the Adriatic (Storelli et al., 2007) however PCB153 levels in this present study are much lower ranging from 0.64 to $5.3 \mathrm{ng} \mathrm{g}^{-1}$ (ww).

\subsection{Brominated flame retardants}

Table 4 presents concentration data for a range of BFR compounds in the five composite eel samples where BFRs were analysed. Upperbound levels of the $\Sigma 11$ PBDE congeners ranged from 1.01 to $7.05 \mathrm{ng} \mathrm{g}^{-1}$ wet weight in the Burrishoole and River Suir samples respectively. These data are comparable to those of a recent survey by the UK food standards (FSA) agency, which determined an upperbound total of $4.88 \mathrm{ng} \mathrm{g}^{-1}$ wet weight for the $\Sigma 11$ PBDE congeners in a composite eel sample from British waters (Food Standards Agency, 2006).

The majority of the PBDE burden is accounted for by PBDEs 47, 100, 153 and 154, with PBDE47 the most prevalent, its concentrations ranging from 0.52 to $5.15 \mathrm{ng} \mathrm{g}^{-1}$ (ww) in the Burrishoole and River Suir samples respectively. Santillo et al. (2005) reports that levels of PBDE47 were low in two Irish samples (not detected to $0.2 \mathrm{ng} \mathrm{g}^{-1} \mathrm{ww}$ ) compared to those determined in eels from other European countries. Eels from Germany ranged from 7.9 to $17.0 \mathrm{ng} \mathrm{g}^{-1}$ (ww), while one composite sample from the UK showed PBDE47 levels of $46.0 \mathrm{ng} \mathrm{g}^{-1}$ (ww). PBDE47 levels of $4.50 \mathrm{ng} \mathrm{g}^{-1}$ (lw) have been 
reported in eels from German waters (Lepom et al., 2002). In this present study PBDE183 concentrations were low (not detected to $0.02 \mathrm{ng} \mathrm{g}^{-1} \mathrm{ww}$ ) indicating that eels in Irish waters are primarily exposed to penta-mixtures rather than to octa-formulations.

Van Leeuwen and de Boer (2008) report levels of PBDE congeners (PBDE 28, 47, 99, 100154 (+PBB153), 183 and 209) from 1.40 to $379 \mathrm{ng} \mathrm{g}^{-1}$ wet weight in freshwater eels from the Netherlands with PBDE 47 and 100 the dominant PBDE congeners, the low levels/absence of PBDE99 as opposed to other fish species suggesting a potential elimination/metabolism in eels.

Roosens et al. (2008) report the sum of 10 PBDEs ( $\mathrm{n}=7$ samples) in the range 660 to $1010 \mathrm{ng} \mathrm{g}^{-1}$ (1w) while total HBCD was determined in the range 2600 to $10100 \mathrm{ng} \mathrm{g}^{-1}$ (lw). Roosens et al. (2008) suggest that eel as a sedentary species are a good indicator of more localised pollution and that congener specific differences in the uptake and biotransformation of PBDEs together with their higher lipid content may be responsible for observed profile differences compared to more migratory fish.

\section{6 $H B C D$}

Within the scope of this present study, a screening exercise for the levels of total HBCD isomers was completed for all five 2005 samples with total HBCD concentrations

determined between 1.2-15 $\mathrm{ng} \mathrm{g}^{-1}$ (ww), corresponding to 7.4 to $166 \mathrm{ng} \mathrm{g}^{-1}$ total HBCD (lw). The two samples at the upper end of the range were further re-analysed on an isomer specific basis by LC/MS by the Central Science Laboratory, York, England (table 
4). In these samples $\alpha$-HBCD was found to contribute the majority (89 to $94 \%$ ) of the total HBCD burden. It should be noted that these analysis were completed by means of GC-MS techniques; Van Leeuwen and deBoer (2008) suggest this technique may over estimate HBCD concentrations and that HPLC/ESI-MSMS may be a more suitable means of deriving HBCD data..

The UK FSA report levels of $5.11 \mathrm{ng} \mathrm{g}^{-1}$ (ww) for $\alpha$-HBCD in eels, with these results being the highest value recorded in 48 diverse fisheries products analysed (FSA, 2006). Santillo el al. (2005) report eel tissues concentrations of HBCD of the order $(<1$ to $>50$ $n g \mathrm{~g}^{-1} \mathrm{ww}$ ) for a range of composite eel samples in European waters. Irish eels in the Santillo et al. (2005) study showed no detectable residues in one sample (Lough Furnace) and a level of $3 \mathrm{ng} \mathrm{g}^{-1}$ (ww) in a further sample from the River Owengarve.

Morris et al. (2004) report that concentrations of HBCD in yellow eels from the Scheldt and River Leie reflect the spatial distribution of HBCD found in sediments in the area. The author suggests that the study provides evidence of HBCD bioaccumulation at this trophic level and biomagnification in the ascending aquatic food chain, justifying risk assessment studies at the ecosystem level. Janak et al. (2005) reported levels of $\alpha$-HBCD in the range of $1.8-7.0 \mathrm{ng} \mathrm{g}^{-1}$ (ww) in eels from the Scheldt while levels of $\gamma$-HBCD ranged from 0.5 to $0.8 \mathrm{ng} \mathrm{g}^{-1}$ (ww). Total HBCD levels in eels from the Netherlands ranging from $<0.1$ to $210 \mathrm{ng} \mathrm{g}^{-1}$ (ww) have been reported by van Leeuwen and de Boer (2008). 


\subsection{TBBPA}

TBBPA was not detected (LODs $<0.03$ to $<0.2 \mathrm{ng} \mathrm{g}^{-1} \mathrm{ww}$ ) in any of the five initial samples analysed in this study. Recoveries of spiked recovery standards in this current study were low (table 4 ) ranging from $25-50 \%$ between the five samples; this may be as a result of TBBPA binding to other endogenous compounds in muscle tissue such as proteins (Schauer et al., 2006). In general relatively low concentrations of TBBPA tend to occur in aquatic biota for a number of reasons. TBBPA is generally chemically bound to the polymer matrix of the end product thereby potential emissions of TBBPA are likely to be limited compared to that of other BFR compounds (Covaci et al., 2008). TBBPA has lower bioaccumulation potential than $\mathrm{HBCD}$ due in part to low partition rates to the particulate and organic carbon compartments of sediments and structural phenolic groups have been reported to allow direct phase-II biotransformation. Further to this the polar nature of TBBPA can subject it to metabolism and elimination from the organism (Morris et al., 2004).

Generally low levels of TBBPA in biota from the Scheldt basin with concentrations ranging from $<0.1$ to $13 \mathrm{ng} \mathrm{g}^{-1}$ (lw) have been recorded (Morris et al., 2004). TBBPA residues were not detected (detection limits ranging from 10-180 $\mathrm{ng} \mathrm{g}^{-1} \mathrm{lw}$ ) in any of the 20 pooled samples reported by Santillo et al. (2005), while de Boer et al. (2002 and 2003) reported that concentrations appear to be similar or even lower in other freshwater and marine species compared to those determined in eels. TBBPA was also analysed as part of the UK FSA study but residues were not detected above the limit of detection in 48 
fisheries products (Food Standards Agency, 2006). On the basis of this study the UK committee on toxicity of chemicals in food, consumer products and the environment concluded that the levels of TBBPA detected in fish and shellfish do not raise toxicological concerns and that estimated dietary exposure seems to have limited implications for health.

\section{8 $P B B$}

Individual PBB levels were low with a range of congeners determined in only three of the five samples suggesting low usage/transport of PBBs to environments in which these eels were sampled (table 3). Upperbound 5 5PBB ranged from 0.005 to $0.127 \mathrm{ng} \mathrm{g}^{-1}$ (ww) for the 5 samples analysed. Levels of PBBs were similarly low in the UK FSA survey of 48 fisheries products, reporting levels of $0.016 \mathrm{ng} \mathrm{g}^{-1}$ (ww) for the $\Sigma 6 \mathrm{PBBs}$ in one composite eel sample (Food Standards Agency, 2006).

\subsection{Organochlorine pesticides.}

OCPs were only measured in the initial five eel samples. Overall levels were low. p,p'DDE was found to be the most abundant compound in the samples followed by dieldrin, p,p'DDD and p,p'DDT. Toxaphene and endrin residues were only detected in one sample (MSC/05/1140) from the Burrishoole catchment (table 4). Trans-nonachlor was found to be the most abundant chlordane compound contributing (42-56\%) of the total chlordane contaminant burden. $\alpha$-chlordane was found in higher concentrations than the $\gamma$-isomer in each of the eel samples in this present study. Heptachlor epoxide is the primary oxidation metabolite of heptachlor with the epoxide form being more 
persistent in the environment than the parent heptachlor, which was not detected in eel samples.

$\gamma-\mathrm{HCH}$ levels ranged from not detected to $0.45 \mathrm{ng} \mathrm{g}^{-1}$ (ww) $\left(2.1 \mathrm{ng} \mathrm{g}^{-1} \mathrm{lw}\right)$ and are lower than concentrations (6.33 to $707 \mathrm{ng} \mathrm{g}^{-1} \mathrm{lw}$ ) in eels from the Orbetello lagoon in Italy reported by Corsi et al. (2005). $\beta$ - $\mathrm{HCH}$ was detected in four samples in the range 0.06 to $0.31 \mathrm{ng} \mathrm{g}^{-1}(\mathrm{ww})$ while the $\delta$ - $\mathrm{HCH}$ isomer was not detected in any of the five samples. Upperbound p,p'DDE levels (11 to $77 \mathrm{ng} \mathrm{g}^{-1} \mathrm{lw}$ ) were similar to those of the Corsi et al. (2005) study (17.1 to $94.6 \mathrm{ng} \mathrm{g}^{-1} \mathrm{lw}$ ). Upperbound EDDTs levels in this study ranged from 2.12 to $10.2 \mathrm{ng} \mathrm{g}^{-1}$ (ww) (13.6 to $111 \mathrm{ng} \mathrm{g}^{-1} \mathrm{lw}$ ). Corsi et al. (2005) reported upperbound EDDTs in the range 22.9 to $98.4 \mathrm{ng} \mathrm{g}^{-1}$ (lw) in Italian eels. A number of contaminant studies determine the $\mathrm{p}$, p'-DDE/Total DDT ratio in order to assess the chronology of DDT inputs. Aguilar (1984) states that a ratio $>0.6$ is indicative of a stable system with no new DDT inputs. In the current study, p, p'-DDE/Total DDT ratios determined in eels muscle tissue ranged from 0.69 to 0.78 , suggesting that eel DDT residues are derived from historic contamination.

\subsection{Summary consumer risk assessment.}

Several studies carried out by the Food Safety Authority of Ireland, the Marine Institute and a study by An Board Iascaigh Mhara (BIM) have indicated that levels of PCDDs in Irish food (excluding eel) are relatively low (Food Safety Authority of Ireland, 2004; Gruemping et al., 2004; Tlustos et al., 2006). These studies indicate that levels of PCDD/Fs and DL-PCBs found in Irish fish are lower than those found in the more 


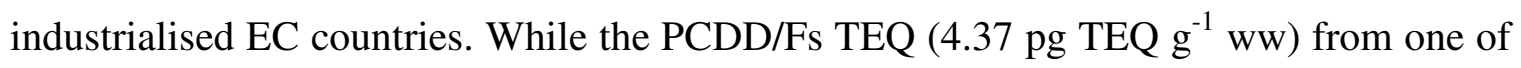
the three Burrishoole samples was found to marginally exceed EU legislative limits (4 pg TEQ $\mathrm{g}^{-1} \mathrm{ww}$ ) for PCDDs in eel muscle, it should be noted that eels currently form a small proportion of the diet of the Irish consumer. Eels may provide a much greater contribution to the diets of other nations, thus the risk to the consumer may vary between countries and individual consumer preferences. Moreover as PCB concentrations were low the total PCDD/F TEQ for all samples including the initial 2005 Burrishoole sample (4.93 PCDD/F and WHO-PCB TEQ $\mathrm{pg} \mathrm{g}^{-1}$ ww) is well within the total EC legislative limit for PCDD/F /WHO-PCB TEQ $\mathrm{pg} \mathrm{g}^{-1}$ (ww) in eels.

\subsection{Contaminant related effects on eel health}

Belpaire et al. (2009) report that the eel, due to its characteristic lifecycle, is very sensitive to the bioaccumulation of contaminants, although effects are difficult to measure in the continental immature phase. However, the direct link between the reported effects at this sub-cellular level and the response on population level is yet to be demonstrated. Belpaire et al. (2009) additionally reports that where spawner quality is poor and lipid content low, silver eels may not contribute to the overall spawning and recruitment of the European stock. Feunteun (2002) and Versonnen et al. (2004) report that while contaminant lethal effects in adult eels generally only occur at very high exposure levels, sub-lethal effects on physiology and on spawning success on reaching sexual maturity cannot be discounted. The potential for contaminant and/or lipid level associated effects on aquatic biota have been documented by a number of authors (for example (Boetius and Boetius, 1980; Lassiter and Hallam, 1990; Tillett, 1999; Feunteun, 
2002; Versonnen et al., 2004; Corsi et al., 2005; Palstra et al., 2006; Maes et al., 2008) and are thus not further discussed here.

Assuming the hypothesis of a relationship between lipid content in yellow and in emigrant silver eel, poor lipid content in yellow eel would indicate low energy reserves in silver eel. While low lipid levels were observed in the described eels, further research into the potential for contaminant and lipid level related biological effects is merited.

\section{Conclusions}

This study provides valuable data for a range of contaminants and extractable lipid levels in eel muscle tissue. Extractable lipid levels were lower in the two yellow eel samples compared to those in the silver eels, with these relatively low levels being consistent with the observations of Belpaire. With the unexpected exception of higher substituted PCDD, (especially OCDD) congener levels in one sample from the Burrishoole region, POP levels in general are low in eels from Irish waters compared to those in other countries. Further investigations into the potential source within the Burrishoole catchment are currently subject to a separate investigation. The merits of the use of eels as a biomonitoring tool for chemical environmental contamination have been demonstrated. While POP levels observed in eel muscle from this study are relatively low, the potential for factors such as localised contamination, and/or potential mobilization of lipid reserves to other organs (as a response to beginning of migration) need to be considered when evaluating the potential for health effects in eels. 


\section{References}

Aguilar, A., 1984. Relationship of DDE/DDT in marine mammals to the chronology of DDT input into the ecosystem. Can. J. of Fish and Aquatic Sci. 41, 840-844.

Alaee, M., Arias, P., Sjödin, A., Bergman, A., 2003. An overview of commercially used brominated flame retardants, their applications, their use patterns in different countries/regions and possibly modes of release. Environ. International 29, 683-689.

Belpaire, C. G. J., G. Goemans, C. Geeraerts, P. Quataert, K. Parmentier, P. Hagel, J. De Boer. Decreasing eel stocks: survival of the fattest? Ecology of Freshwater Fish. Ecology of Freshwater Fish, Vol. 18, No. 2., pp. 197-214. (2009).

Bertin, L., 1956. Eels: A Biological Study. Cleaver-Hume Press Ltd., London.

Birnbaum, L.S., Staskal, D.F., 2004. Brominated flame retardants: cause for concern?. Environ. Health Persp. 112, 9-17.

Boetius, I., Boetius, J., 1980. Experimental maturation of female silver eels, Anguilla anguilla. Estimates of fecundity and energy reserves for migration and spawning. Dana 1, $1-28$.

Corsi, I., Mariottini, M., Badesso, A., Caruso, T., Borghesi, N., Bonacci, S., Iacocca, A., Focardi, S., 2005. Contamination and sub-lethal toxicological effects of persistent organic 
pollutants in the European eel (Anguilla anguilla) in the Orbetello lagoon, Tuscany, Italy. Hydrobiologia 550, 237-249.

Covaci, A., Voorspoels, S., Abdallah, M.A.E., Geens, T., Harrad, S., Law, R., 2008. Analytical and environmental aspects of the flame retardant tetrabromobisphenol-A and its derivatives. Journal of Chrom. A 1216 (2009), pp. 346-363.

de Boer, J., Allchin, C., Zegers, B., Boon, J.P., Brandsma, S.H., Morris, S., Kruijt, A.W., van der Veen, I., van Hesselingen, J.M., Haftka, J.J.H., 2002. HBCD and TBBPA in sewage sludge, sediments and biota, including interlaboratory study. RIVO Report No. C033:02 Sept (2002).

de Boer, J., de Boer, K., Boon, J.P., 2000. In: Paasivirta, J. (Ed.). New types of persistent halogenated compounds. Springer-Verlag, 61-95.

de Boer, J., Hagel, P., 1994. Spatial differences and temporal trends of chlorobiphenyls in yellow eel (Anguilla anguilla) from inland waters of the Netherlands. Sci. Total Environ. $141,155-174$.

de Boer, J., Wester, P.G., van der Horst, A., Leonards, P.E.G., 2003. Polybrominated diphenyl ethers in influents, suspended particulate matter, sediments, sewage treatment plant and effluents and biota from the Netherlands. Environ. Poll. 122, 63-74. 
de Boer J., van der Valk, F., Kerkhoff, M. A. T., Hagel, P., Brinkman U. A. Th., 1994. An 8-Year Study on the Elimination of PCBs and Other Organochlorine Compounds from Eel (Anguilla anguilla) under Natural Conditions. Environ. Sci. Technol. 28, 22422248

de Swart, R., Ross, P.S., Vedder, L.J., Timmerman, H.H., Heisterkamp, S., Van Loveren, H., Vos, J.G., Reijnders, P.J.H., Osterhaus, A.D.M.E., 1994. Impairment of immune function in harbor seals (Phoca vitulina) feeding on fish from polluted waters. Ambio. 23, 155-159.

Dekker, W., 2003. Status of the European eel stock and fisheries. In Aida, K., Sukamoto, K.T., Yamauchi, K. (Eds.). Eel Biology. House, City, Country, pp. 237-254.

European Commission. (2006a) Regulation 1907/2006 of the European Parliament and of the Council of December 18, 2006. Off. J. Eur. Comm. L 396 (2006) 1.

European Commission. (2006b) Commission Regulation (EC) No 1881/2006 of 19 December 2006 setting maximum levels for certain contaminants in foodstuffs. OJ L 364, 20.12.2006.

European Commission. (2000) Regulation 2364/2000/EC of October 25, 2000 Concerning the fourth list of priority substances as foreseen under Council Regulation (EEC) No. 793/93 Of. J. Eur. Comm L 273 (2000) 5. 
European Commission. European Risk Assessment Report on 2,2'6,6'-tetrabromo-4,4'isopropylidenediphenol (tetrabromobisphenol-A or TBBPA). Part II, Human health, vol. 63, European Commission, Joint Research Centre, European Chemicals Bureau, EUR22161E, 2006.

EU. EU Working Document 2005. "Current national legislations on PCBs in the EU 2005" Unpublished.

European Food Safety Authority. 2005. Opinion of the Scientific Panel on contaminants in the food chain [CONTAM] related to the presence of non dioxin-like polychlorinated biphenyls (PCB) in feed and food, Question number: EFSA-Q-2003-114. The EFSA Journal 284. 1-137

Feunteun, E., 2002. Restoration and management of the European eel: an impossible bargain?. Ecological Engineering 18, 575-591.

Food Safety Authority of Ireland (2004). Investigation into levels of dioxins, furans, PCBs and PBDEs in Irish food 2004. http://www.fsai.ie/publications/reports/dioxins.pdf

Food Standards Agency 2006. Brominated chemicals in farmed and wild fish and shellfish and fish oil dietary supplements. (2006) http://www.food.gov.uk] 
Geomans, G., Belpaire, C., Raemaekers, M., Guns, M., 2003. The Flemish eel pollution monitoring network 1994-2001: polychlorinated biphenyls, organochlorine pesticides and heavy metals in eel. Institute for Forestry and Game Management, report IBW.Wb.V.R.2003.99.

Geyer, H.J., Rimkus, G.G., Scheunert, I., Kaune, A., Schramm, K.W., Kettrup, A., Zeeman, M., Muir, D.C.G., Hansen, L.G., Mackay, D., 2000. Bioaccumulation and occurrence of endocrine-disrupting chemicals (EDCs), persistent organic pollutants (POPs), and other organic compounds in fish and other organisms including humans. In: Beek, B. (Ed.). The Handbook of Environ. Chem. 2, Part J Bioaccumulation, SpringerVerlag, Berlin, Heidelberg.

Giesy, J.P. and Kannan, K., 1998. Dioxin-like and non-dioxin-like toxic effects of polychlorinated biphenyls (PCBs): implications for risk assessment. Crit. Rev. Toxicol. $28,511-569$.

Gruemping, R., Hamm, S., Stegemann, D., Maulshagen, A., 2004. Levels of polychlorinated dibenzo(p)dioxins, dibenzofurans and dioxin-like PCBs in Irish farmed salmon. Organohalogen Compounds 66, 1977-1984.

ICES Report of the ICES/EIFAC. Working Group on Eels. International Council for the Exploration of the Sea. ICES CM/ACFM:16 Jan (2006). 
International Agency for Research on Cancer (IARC) 1997. Polychlorinated Dibenzopara-dioxins and Polychlorinated Dibenzofurans. IARC Monogr. Eval. Carcinog. Risks Hum. 69.

Janák, K., Covaci, A., Voorspoels, S., Becher, G., 2005. Hexabromocyclododecane in marine species from the Western Scheldt Estuary: Diastereoisomer- and EnantiomerSpecific Accumulation. 1987-1994. Environ. Sci. Technol. 39.

Kitamura, S., Jinno, N., Ohta, S., Kuroki, H., Fujimoto, N., 2002. Thyroid hormonal activity of the flame retardants tetrabromobisphenol A and tetrachlorobisphenol A. Biochem. Biophys. Res. Commun. 293, 554-559.

Lassiter, R.R., Hallam, T.G., 1990. Survival of the fattest: implications for acute effects of lipophilic chemicals on aquatic populations. Environ. Toxicol. Chem. 9, 585.

Legare, M.E., Hanneman W.H., Barhoumi R., Burghardt R.C., Tiffany-Castiglioni E., 2,3,7,8-Tetrachlorodibenzo-p-dioxin alters hippocampal astroglia-neuronal gap junctional communication. Neurotoxicology 2000;21:1109-16

Lepom, P., Karasova, T., Sawal, G., 2002. Occurrence of polybrominated diphenylethers in freshwater fish from Germany. Organohalogen Compounds 58, 209-212. 
Maes, J., Belpaire, C., Goemans, G., 2008. Spatial variations and temporal trends between 1994 and 2005 in polychlorinated biphenyls, organochlorine pesticides and heavy metals in European eel (Anguilla anguilla L.) in Flanders, Belgium. Environmental Pollution 153, 223-237.

Meironyte, D., Noren, K., Bergman, A., 1999. Analysis of polybrominated diphenyl ethers in Swedish human milk; a time-related trend study, 1972-1997. J. Toxicol. Environ. Health A. 58, 329-341.

Moriarty, C., 1988. The eel in Ireland; Went Memorial Lecture, 1987, R.D.S. Occas. Paper, 4.

Morris, S., Allchin, C.R., Zegers, B.N., Haftka, J.J.H., Boon, J.P., Belpaire, C., Leonards, P.G., van Leeuwen, S.P.J., de Boer, J., 2004. Distribution and fate of HBCD and TBBPA brominated flame retardants in North Sea estuaries and aquatic food webs. Environ. Sci. Technol. 38, 5497-5504.

Palstra, A.P., Van Ginneken, V.J.T., Murk. A.J., Van Den Thillart, G.E.E.J.M., 2006. Are dioxin-like contaminants responsible for the eel (Anguilla anguilla) drama? Naturwissenschaften. 93, 145-148.

Poole, W.R., Reynolds, J.D., 1996. Growth rate and age at migration of Anguilla anguilla. J. Fish Biology 48, 633-642. 
Poole, W.R., Reynolds, J.D.R., Moriarty, C., 1990. Observations on the silver eel migrations of the Burrishoole river system, Ireland; 1959 to 1988 . Int. Revue. Ges. Hydrobiol. 75, 807-815.

Reijnders, P.J.H., 1986. Reproductive failure in common seals feeding on fish from polluted coastal waters. Nature 324, 456-457.

Reijnders, P.J.H., 1994. Toxicokinetics of chlorobiphenyls and associated physiological responses in marine mammals, with particular reference to their potential for ecotoxicological risk assessment. Sci. Tot. Environ. 154, 229-236.

Roosens, L., Dirtu, A.C., Goemans, G., Belpaire, C., Gheorghe, A., Neels, H., Blust, R., Covaci, A., 2008. Brominated flame retardants and polychlorinated biphenyls in fish from the river Scheldt, Belgium. Environment International 34, 976-983.

Ryan, J., Gasiewicz, T., Brown, J., 1990. Human body burden of polychlorinated dibenzofurans associated with toxicity based on the Yusho and Yucheng incidents. Fundam. Appl. Toxicol. 15, 722-731.

Santillo, D., Johnston, P., Labunska, I., Brigden, K., 2005. Widespread presence of brominated flame retardants and PCBs in eels (Anguilla anguilla) from rivers and lakes in 10 European countries. Greenpeace Research Laboratories Technical Note 12:56. 
Schauer, U.M.D., Völkel, W., Dekant, W., 2006. Toxicokinetics of tetrabromobisphenol A in humans and rats after oral administration. Toxicol. Sci. 91, 49-58.

Spiegelstein, M., 2000. Brominated compounds: addressing the gap in scientific knowledge. In: de Boer, J., Leonards, P.E.G., Boon, J., Law, R.J. (Eds.). Proceedings of BSEF workshop on polybrominated diphenyl ethers (PBDEs): global distribution of PBDEs. Ijmuiden, Netherlands.

Stachel, B., Christoph, E.H., Götz, R., Herrmann, T., Krüger, F., Kühn, T., Lay, J., Löffler, J., Päpke, O., Reincke, H., Schröter-Kermani, C., Schwartz, R., Steeg, E., Stehr, D., Uhlig, S., Umlauf, G., 2007. Dioxins and dioxin-like PCBs in different fish from the river Elbe and its tributaries, Germany. Journal of Hazardous Materials 148, 199-209.

Storelli, M.M., Barone, G., Garofalo, R., Marcotrigiano, G.O., 2007. Metals and organochlorine compounds in eel (Anguilla anguilla) from the Lesina lagoon, Adriatic Sea (Italy). Food Chemistry 100, 1337-1341.

Tesch, F.W., 2003. The Eel. Blackwell Publishing, Oxford.

Tillett, D.E., 1999. The toxic equivalents approach for fish and wildlife. Human and Ecological Risk Assessment 5, 25-32. 
Tlustos, C., McHugh, B., Pratt, I., Tyrrell, L., McGovern, E., 2006. Investigation into levels of dioxins, furans, polychlorinated biphenyls and brominated flame retardants in fishery produce in Ireland. Marine Institute, Marine Environment and Health Series, No.26.

Van den Berg, M., Birnbaum, L., Bosveld, A.T.C., Brunström, B., Cook, P., Feeley, M., Giesy, J.P., Hanberg, A., Hasegawa, R., Kennedy, S.W., Kubiak, T., Larsen, J.C., Rolaf van Leeuwen, F.X., Djien Liem, A.K., Nolt, C., Peterson, R.E., Poellinger, L., Safe, S, Schrenk, D., Tillitt, D., Tysklind, M., Younes, M., Wærn, F., Zacharewski, T., 1998. Toxic Equivalency Factors (TEFs) for PCBs, PCDDs, PCDFs for Humans and Wildlife. Environ. Health Persp. 106.

van den Berg, M., Birnbaum, L. S., Denison, M., De Vito, M, Farland, W., Feeley, M., Fiedler, H., Hakansson, H., Hanberg, A., Haws, L., Rose, M., Safe, S., Schrenk, D., Tohyama, C., Tritscher, A., Tuomisto, J., Tysklind, M., Walker, N., and Peterson, R E. (2006) The 2005 World Health Organization Re-evaluation of Human and Mammalian Toxic Equivalency Factors for Dioxins and Dioxin-like Compounds. Toxicol Sci. October ; 93(2): 223-241.

Van Leeuwen, S.P., De Boer, J., 2008. Brominated flame retardants in fish and shellfish levels and contribution of fish consumption to dietary exposure of Dutch citizens to HBCD. Mol. Nutr. Food Res. 52, 194-203. 
Versonnen, B.J, Goemens, G., Belpaire, C., Janssen, C.R., 2004. Vitellogenin content in European eel (Anguilla anguilla) in Flanders, Belgium. Environ. Poll. 128, 363-371.

Vos, J.G., Becher, G., van den Berg, M., de Boer, J., Leonards, P.E.G., 2003. Brominated flame retardants and endocrine disruption. Pure and Applied Chem. 75, 2039-2046. 
Table 1: Sampling details, length (cm) and age (yrs) and extractable lipid content (\%) for both the pooled sampled individuals and the overall population from which the sample was taken (in parenthesis) in eels from Irish waters.

\begin{tabular}{|c|c|c|c|c|c|c|c|}
\hline MI Reference & MSC/05/1119 & MSC/05/1120 & MSC/05/1121 & MSC/05/1122 & MSC/05/1140 & MSC/07/1133 & MSC/07/1134 \\
\hline Ecotype & Yellow & Silver & Silver & Silver & Silver & Silver & Yellow \\
\hline Location & $\begin{array}{l}\text { Waterford, } \\
\text { River Suir }\end{array}$ & $\begin{array}{l}\text { Mayo, } \\
\text { L. Conn }\end{array}$ & $\begin{array}{c}\text { Galway, } \\
\text { River Corrib }\end{array}$ & $\begin{array}{l}\text { Monaghan, } \\
\text { River Fane }\end{array}$ & $\begin{array}{c}\text { Burrishoole, } \\
\text { Co. Mayo }\end{array}$ & $\begin{array}{c}\text { Burrishoole, } \\
\text { Co. Mayo }\end{array}$ & $\begin{array}{l}\text { L. Feeagh, } \\
\text { Co. Mayo }\end{array}$ \\
\hline Date Fished & NA & $11 / 08 / 2005$ & $10 / 27 / 2005$ & $11 / 04 / 2005$ & $10 / 9 / 2005$ & $07 / 25 / 2007$ & $10 / 9 / 2007$ \\
\hline Individuals (n) & 10 & 9 & 10 & 10 & 10 & 12 & 15 \\
\hline Mean Length (cm) & $40.1(46.9)$ & $47.5(53.1)$ & $46.4(52.2)$ & $45.7(43.7)$ & $48.8(52.8)$ & $46.4(45.7)$ & $46.1(46.1)$ \\
\hline Std. Dev. $(\mathrm{cm})$ & $9.92(10.7)$ & $8.73(6.17)$ & $9.54(6.97)$ & $11.6(9.62)$ & $9.69(4.29)$ & $8.5(9.5)$ & $9.6(10.3)$ \\
\hline Mean Age (yrs) & $16.0(11.8)$ & $19.8(23.2)$ & $19.4(17.2)$ & $17.9(18.2)$ & $32.3(27.6)$ & NA (25.1) & $\mathrm{NA}\left(22.0^{1}\right)$ \\
\hline Extractable Lipid (\%) & 9.18 & 15.3 & 14.3 & 16.0 & 20.9 & 17.9 & 8.28 \\
\hline
\end{tabular}

${ }^{1}$ L.Feeagh age sample from 2001. 
Table 2 Concentrations of marker-PCBs ( $\mathrm{ng} \mathrm{g}^{-1}$ ), dioxins, furans and dioxin like PCB levels in eel muscle from Irish waters ( $\mathrm{pg} \mathrm{g}^{-1}$ wet weight); TCDD Toxic Equivalent Factors (TEFs) and summary upperbound TEQs for Dioxins/Furans and Dioxin like PCBs are also presented ( $\mathrm{pg} \mathrm{g}^{-1}$ wet weight).

\begin{tabular}{|c|c|c|c|c|c|c|c|c|c|}
\hline PCDDs/PCDFs & WHO-TEF & FISH TEF & MSC/05/1119 & MSC/05/1120 & MSC/05/1121 & $\mathrm{MSC} / 05 / 1122$ & MSC/05/1140 & MSC/07/1133 & MSC/07/1134 \\
\hline 2.3.7.8-Tetra-CDD & 1 & 1 & 0.04 & 0.03 & 0.02 & 0.03 & 0.06 & 0.03 & 0.02 \\
\hline 1.2.3.7.8-Penta-CDD & 1 & 1 & 0.10 & 0.08 & 0.09 & 0.09 & 2.00 & 1.28 & 0.66 \\
\hline 1.2.3.4.7.8-Hexa-CDD & 0.1 & 0.5 & 0.03 & 0.08 & 0.04 & 0.06 & 5.30 & 2.75 & 1.22 \\
\hline 1.2.3.6.7.8-Hexa-CDD & 0.1 & 0.01 & 0.16 & 0.17 & 0.10 & 0.23 & 13.0 & 6.57 & 2.99 \\
\hline 1.2.3.7.8.9-Hexa-CDD & 0.1 & 0.01 & 0.04 & 0.04 & n.d.(0.02) & 0.03 & 2.20 & 1.11 & 0.54 \\
\hline 1.2.3.4.6.7.8-Hepta-CDD & 0.01 & 0.001 & 0.10 & 0.11 & 0.05 & 0.08 & 13.00 & 6.57 & 3.62 \\
\hline OCDD & 0.0001 & 0.0001 & n.d.(0.3) & n.d.(0.3) & n.d.(0.3) & n.d.(0.3) & 42.0 & 23.6 & 13.2 \\
\hline 2.3.7.8-Tetra-CDF & 0.1 & 0.05 & n.d.(0.3) & n.d.(0.02) & n.d.(0.3) & n.d.(0.04) & n.d.(0.02) & $<0.02$ & $<0.01$ \\
\hline 1.2.3.7.8-Penta-CDF & 0.05 & 0.05 & 0.02 & 0.01 & 0.02 & 0.02 & 0.09 & 0.02 & $<0.01$ \\
\hline 2.3.4.7.8-Penta-CDF & 0.5 & 0.5 & 0.15 & 0.10 & 0.06 & 0.09 & 0.12 & 0.10 & 0.06 \\
\hline 1.2.3.4.7.8-Hexa-CDF & 0.1 & 0.1 & 0.05 & 0.06 & 0.03 & 0.06 & 0.22 & 0.10 & 0.05 \\
\hline 1.2.3.6.7.8-Hexa-CDF & 0.1 & 0.1 & 0.03 & 0.04 & 0.02 & 0.03 & 0.12 & 0.06 & 0.04 \\
\hline 1.2.3.7.8.9-Неxa-CDF & 0.1 & 0.1 & n.d.(0.02) & n.d.(0.02) & n.d.(0.02) & n.d.(0.02) & n.d.(0.02) & $<0.01$ & $<0.01$ \\
\hline 2.3.4.6.7.8-Hexa-CDF & 0.1 & 0.1 & 0.09 & 0.09 & 0.08 & 0.07 & 0.25 & 0.07 & 0.03 \\
\hline 1.2.3.4.6.7.8-Hepta-CDF & 0.01 & 0.01 & 0.04 & n.d.(0.04) & n.d.(0.04) & n.d.(0.04) & 0.09 & 0.07 & 0.03 \\
\hline 1.2.3.4.7.8.9-Hepta-CDF & 0.01 & 0.01 & n.d.(0.03) & n.d.(0.02) & n.d.(0.04) & n.d.(0.05) & n.d.(0.02) & $<0.01$ & $<0.01$ \\
\hline OCDF & 0.0001 & 0.0001 & n.d.(0.05) & n.d.(0.05) & n.d.(0.07) & n.d.(0.05) & 0.07 & $<0.01$ & $<0.01$ \\
\hline Total 2.3.7.8-PCDD & & & 0.78 & 0.81 & 0.62 & 0.81 & 77.6 & 41.9 & 22.2 \\
\hline Total 2.3.7.8-PCDF & & & 0.52 & 0.44 & 0.42 & 0.46 & 1.01 & 0.47 & 0.26 \\
\hline Total 2.3.7.8-PCDD/PCDF & & & 1.29 & 1.25 & 1.04 & 1.28 & 78.6 & 42.4 & 22.5 \\
\hline \multicolumn{10}{|l|}{$\begin{array}{l}\text { Dioxin Like PCBs } \\
\end{array}$} \\
\hline $\begin{array}{l}\mathbf{3 , 3}, \mathbf{4}, 4^{\prime} \text {-Tetra-CB } \quad 77 \\
\end{array}$ & 0.0001 & 0.0001 & $\begin{array}{ll}\text { n.d.(4) } \\
\end{array}$ & $\begin{array}{ll}\text { n.d.(2) } \\
\text { n. }\end{array}$ & n.d.(3) & n.d.(3) & n.d.(2) & $<0.19$ & 0.46 \\
\hline 3,4,4',5-Tetra-CB 81 & 0.0001 & 0.0005 & n.d.(0.14) & n.d.(0.08) & n.d.(0.08) & n.d.(0.1) & n.d.(0.06) & 0.02 & $<0.02$ \\
\hline 3,3',4,4',5-Penta-CB 126 & 0.1 & 0.005 & 6.30 & n.d.(2) & n.d.(2) & 2.30 & 2.80 & 1.86 & 1.08 \\
\hline 3,3',4,4',5,5'-Неха-СВ 169 & 0.01 & 0.00005 & 2.00 & 1.20 & 1.30 & 1.30 & 1.80 & 0.98 & $<0.61$ \\
\hline Total non-ortho PCB & & & 12.4 & 5.28 & 6.38 & 6.70 & 6.66 & 3.05 & 2.17 \\
\hline 2,3,3',4,4'-Penta-CB 105 & 0.0001 & $<0.000005$ & 853 & 188 & 75 & 429 & 381 & 90 & 40 \\
\hline 2,3,4,4,5-Penta-CB 114 & 0.0005 & $<0.000005$ & 43 & 10 & 8.4 & 36 & 22 & $<10$ & $<10$ \\
\hline 2,3',4,4',5-Penta-CB 118 & 0.0001 & $<0.000005$ & 2783 & 564 & 282 & 1496 & 1077 & 430 & 230 \\
\hline 2',3,4,4',5-Penta-CB 123 & 0.0001 & $<0.000005$ & 43 & 12 & n.d.(9) & 26 & n.d.(10) & 10 & $<10$ \\
\hline 2,3,3',4,4',5,-Неха-СВ 156 & 0.0005 & $<0.000005$ & 311 & 75 & 37 & 170 & 168 & 60 & 30 \\
\hline 2,3,3',4,4',5'-Неха-СB 157 & 0.0005 & $<0.000005$ & 72 & 13 & 12 & 42 & 33 & 20 & 10 \\
\hline $2,3^{\prime}, 4,44^{\prime}, 5,5^{\prime}$-Неха-СB 167 & 0.00001 & $<0.000005$ & 215 & 46 & 38 & 84 & 94 & 40 & 30 \\
\hline 2,3,3',4,4',5,5'-Hepta-CB 189 & 0.0001 & $<0.000005$ & 32 & 11 & 13 & 19 & 16 & 20 & $<10$ \\
\hline Total mono-ortho РCB & & & 4352 & 919 & 474 & 2302 & 1801 & 680 & 370 \\
\hline \multicolumn{10}{|l|}{ TEQs } \\
\hline WHO-TEQ 2.3.7.8-PCDD & & & 0.17 & 0.14 & 0.13 & 0.14 & 4.24 & 2.42 & 1.19 \\
\hline WHO-TEQ 2.3.7.8-PCDF & & & 0.13 & 0.07 & 0.08 & 0.07 & 0.13 & 0.08 & 0.04 \\
\hline WHO-TEQ 2.3.7.8-PCDD/PCDF & & & 0.29 & 0.22 & 0.21 & 0.21 & 4.37 & 2.50 & 1.24 \\
\hline WHO-TEQ non-ortho PCB & & & 0.65 & 0.21 & 0.21 & 0.24 & 0.30 & 0.20 & 0.11 \\
\hline WHO-TEQ mono-ortho PCB & & & 0.59 & 0.13 & 0.07 & 0.32 & 0.26 & 0.10 & 0.05 \\
\hline WHO-TEQ WHO-PCB & & & 1.24 & 0.34 & 0.28 & 0.57 & 0.56 & 0.30 & 0.17 \\
\hline Ratio TEQ PCDD TEQ/PCDF & & & 1.32 & 1.94 & 1.65 & 2.16 & 33.0 & 31.1 & 26.6 \\
\hline Ratio TEQ non-ortho/mono-ortho & & & 1.11 & 1.67 & 3.18 & 0.76 & 1.14 & 1.95 & 2.10 \\
\hline Marker-PCBs $\left(\right.$ ng g $\left.^{-1}\right)$ & & & MSC/05/1119 & MSC/05/120 & MSC/05/121 & MSC/05/1122 & MSC/05/1140 & MSC/07/1133 & MSC/07/1134 \\
\hline PCB 28 & & & 0.58 & 0.03 & 0.03 & 0.35 & 0.03 & 0.02 & 0.02 \\
\hline PCB 52 & & & 1.4 & 0.13 & 0.06 & 0.9 & 0.21 & 0.12 & 0.06 \\
\hline РCB 101 & & & 1.55 & 0.2 & 0.11 & 0.69 & 0.27 & 0.23 & 0.1 \\
\hline РCB 118 & & & 2.78 & 0.56 & 0.28 & 1.5 & 1.08 & 0.43 & 0.23 \\
\hline РCB 138 & & & 4.11 & 1.01 & 0.56 & 1.83 & 2.13 & 1.31 & 0.77 \\
\hline РCB 153 & & & 5.3 & 1.19 & 0.64 & 1.62 & 2.09 & 1.33 & 0.89 \\
\hline РCB 180 & & & 2.33 & 0.51 & 0.26 & 0.75 & 0.96 & 0.42 & 0.3 \\
\hline$\Sigma$ Marker-PCBs & & & 18 & 3.63 & 1.94 & 7.64 & 6.77 & 3.86 & 2.37 \\
\hline
\end{tabular}

n.d. = not detectable, detection limits in () 
1 Table 3: Concentrations of Brominated flame retardants in eels from Irish waters $\left(\mathrm{ng} \mathrm{g}^{-1}\right.$ 2 wet weight).

3

\begin{tabular}{|c|c|c|c|c|c|}
\hline PBDEs & MSC/05/1119 & MSC/05/1120 & MSC/05/1121 & MSC/05/1122 & MSC/05/1140 \\
\hline PBDE \#17 & 0.011 & 0.0016 & n.d.(0.001) & 0.0042 & n.d.(0.002) \\
\hline PBDE \#28 & 0.065 & 0.017 & 0.0070 & 0.038 & 0.0061 \\
\hline PBDE \#47 & 5.15 & 1.67 & 0.77 & 1.83 & 0.52 \\
\hline PBDE \#66 & 0.099 & 0.053 & 0.015 & 0.064 & 0.017 \\
\hline PBDE \#85 & n.d.(0.0009) & n.d.(0.002) & n.d.(0.001) & n.d.(0.002) & n.d.(0.002) \\
\hline PBDE \#99 & 0.16 & 0.025 & 0.017 & 0.10 & 0.024 \\
\hline PBDE \#100 & 1.26 & 0.33 & 0.20 & 0.40 & 0.16 \\
\hline PBDE \#138 & n.d.(0.002) & n.d.(0.002) & n.d.(0.002) & n.d.(0.002) & n.d.(0.002) \\
\hline PBDE \#153 & 0.072 & 0.055 & 0.031 & 0.12 & 0.052 \\
\hline PBDE \#154 & 0.20 & 0.13 & 0.090 & 0.20 & 0.095 \\
\hline PBDE \#183 & n.d.(0.002) & 0.0038 & 0.0019 & 0.022 & 0.0076 \\
\hline$\Sigma$ 11PBDEs (lower bound) & 7.01 & 2.28 & 1.14 & 2.83 & 1.00 \\
\hline$\Sigma$ 11PBDEs (upper bound) & 7.05 & 2.33 & 1.18 & 2.83 & 1.01 \\
\hline \multicolumn{6}{|l|}{ PBBs } \\
\hline PBB \#15 & 0.0015 & n.d.(0.002) & n.d.(0.001) & n.d.(0.002) & n.d.(0.002) \\
\hline PBB \#49 & n.d.(0.0009) & n.d.(0.002) & n.d.(0.001) & n.d.(0.002) & n.d.(0.002) \\
\hline PBB \#52 & 0.0031 & n.d.(0.002) & n.d.(0.001) & n.d.(0.002) & n.d.(0.002) \\
\hline PBB \#101 & 0.0011 & 0.0018 & n.d.(0.001) & n.d.(0.002) & 0.0040 \\
\hline PBB \#153 & n.d.(0.001) & n.d.(0.002) & n.d.(0.001) & n.d.(0.002) & 0.0027 \\
\hline Total PBBs (Upper Bound) & 0.0076 & 0.0098 & 0.005 & 0.01 & 0.0127 \\
\hline TBBPA & n.d.(0.03) & n.d.(0.05) & n.d.(0.04) & n.d.(0.05) & n.d.(0.2) \\
\hline total HBCD & 15 & 2.2 & 1.2 & 15 & 1.6 \\
\hline$\alpha-\mathrm{HBCD}^{1}$ & 8.9 & NA & NA & 6.0 & NA \\
\hline$\beta-H B C D^{1}$ & 0.48 & NA & NA & 0.18 & NA \\
\hline$\gamma-\mathrm{HBCD}^{1}$ & 0.58 & NA & NA & 0.20 & NA \\
\hline
\end{tabular}

4

$5 \quad{ }^{1}$ isomer specific confirmation analysis completed by CSL York England.

$6 \quad \mathrm{NA}=$ Not analysed

7 n.d. = Not detected detection limit in parenthesis.

8 
9 Table 4: Concentrations of Organochlorine compounds in eel muscle from Irish waters

$10 \quad\left(\mathrm{ng} \mathrm{g}^{-1}\right.$ wet weight).

\begin{tabular}{|c|c|c|c|c|c|}
\hline & MSC/05/1119 & MSC/05/1120 & MSC/05/1121 & MSC/05/1122 & MSC/05/1140 \\
\hline$\beta-\mathrm{HCH}$ & n.d.(0.10) & 0.14 & 0.061 & 0.20 & 0.31 \\
\hline$\alpha-\mathrm{HCH}$ & n.d.(0.1) & 0.21 & 0.22 & 0.19 & 0.29 \\
\hline$\gamma-\mathrm{HCH}$ & 0.21 & 0.16 & n.d.(0.2) & 0.29 & 0.45 \\
\hline$\delta-\mathrm{HCH}$ & n.d.(0.2) & n.d.(0.2) & n.d.(0.2) & n.d.(0.2) & n.d.(0.2) \\
\hline o,p-DDT & 0.038 & 0.041 & 0.037 & n.d.(0.04) & 0.072 \\
\hline p,p'-DDT & 0.31 & 0.27 & 0.14 & 0.17 & 0.55 \\
\hline o,p-DDD & 0.093 & n.d.(0.04) & 0.059 & 0.045 & n.d.(0.04) \\
\hline p,p'-DDD & 2.70 & 0.55 & 0.21 & 1.90 & 0.67 \\
\hline o,p-DDE & 0.047 & n.d.(0.03) & n.d.(0.04) & n.d.(0.04) & n.d.(0.04) \\
\hline p,p'-DDE & 7.10 & 3.20 & 1.60 & 5.00 & 3.10 \\
\hline Hexachlorobenzene & n.d.(0.5) & n.d.(1) & n.d.(0.8) & n.d.(0.9) & n.d.(2) \\
\hline Heptachlor & n.d.(0.2) & n.d.(0.2) & n.d.(0.2) & n.d.(0.2) & n.d.(0.2) \\
\hline cis Heptachlorepoxide & 0.11 & 0.45 & 0.32 & 0.19 & 0.88 \\
\hline trans Heptachlorepoxide & n.d.(0.7) & n.d.(0.7) & n.d.(0.8) & n.d.(0.7) & n.d.(0.8) \\
\hline Aldrin & n.d.(0.1) & n.d.(0.10) & n.d.(0.1) & n.d.(0.1) & n.d.(0.1) \\
\hline Toxaphene 26 & n.d.(0.3) & n.d.(0.3) & n.d.(0.4) & n.d.(0.2) & 0.86 \\
\hline Toxaphene 50 & n.d.(0.3) & n.d.(0.4) & n.d.(0.4) & n.d.(0.3) & 1.2 \\
\hline Toxaphene 62 & n.d.(1) & n.d.(1) & n.d.(1) & n.d.(1) & n.d.(1) \\
\hline Octachlorstyrene & n.d.(0.08) & 0.071 & n.d.(0.08) & n.d.(0.07) & 0.14 \\
\hline Dieldrin & 2.00 & 1.40 & 2.20 & 2.10 & 3.50 \\
\hline Endrin & n.d.(0.1) & n.d.(0.10) & n.d.(0.1) & n.d.(0.1) & 0.16 \\
\hline Mirex & n.d.(0.01) & 0.050 & 0.016 & n.d.(0.02) & 0.20 \\
\hline Endosulphane sulphate & n.d.(0.3) & n.d.(0.2) & n.d.(0.2) & n.d.(0.2) & n.d.(0.2) \\
\hline$\alpha$-Endosulphane & n.d.(0.9) & n.d.(0.8) & n.d.(0.9) & n.d.(0.9) & n.d.(1.0) \\
\hline$\beta$-Endosulphane & n.d.(3) & n.d.(2) & n.d.(3) & n.d.(3) & n.d.(2) \\
\hline$\gamma$-Chlordane & n.d.(0.05) & 0.084 & 0.11 & 0.058 & 0.096 \\
\hline$\alpha$-Chlordane & 0.081 & 0.28 & 0.15 & 0.095 & 0.86 \\
\hline Oxychlordane & n.d.(0.2) & n.d.(0.2) & n.d.(0.2) & n.d.(0.2) & 0.29 \\
\hline Transnonachlor & 0.26 & 0.72 & 0.48 & 0.28 & 1.60 \\
\hline
\end{tabular}


16 Figure 1: Sampling location map for eels collected for contaminants analysis.

17
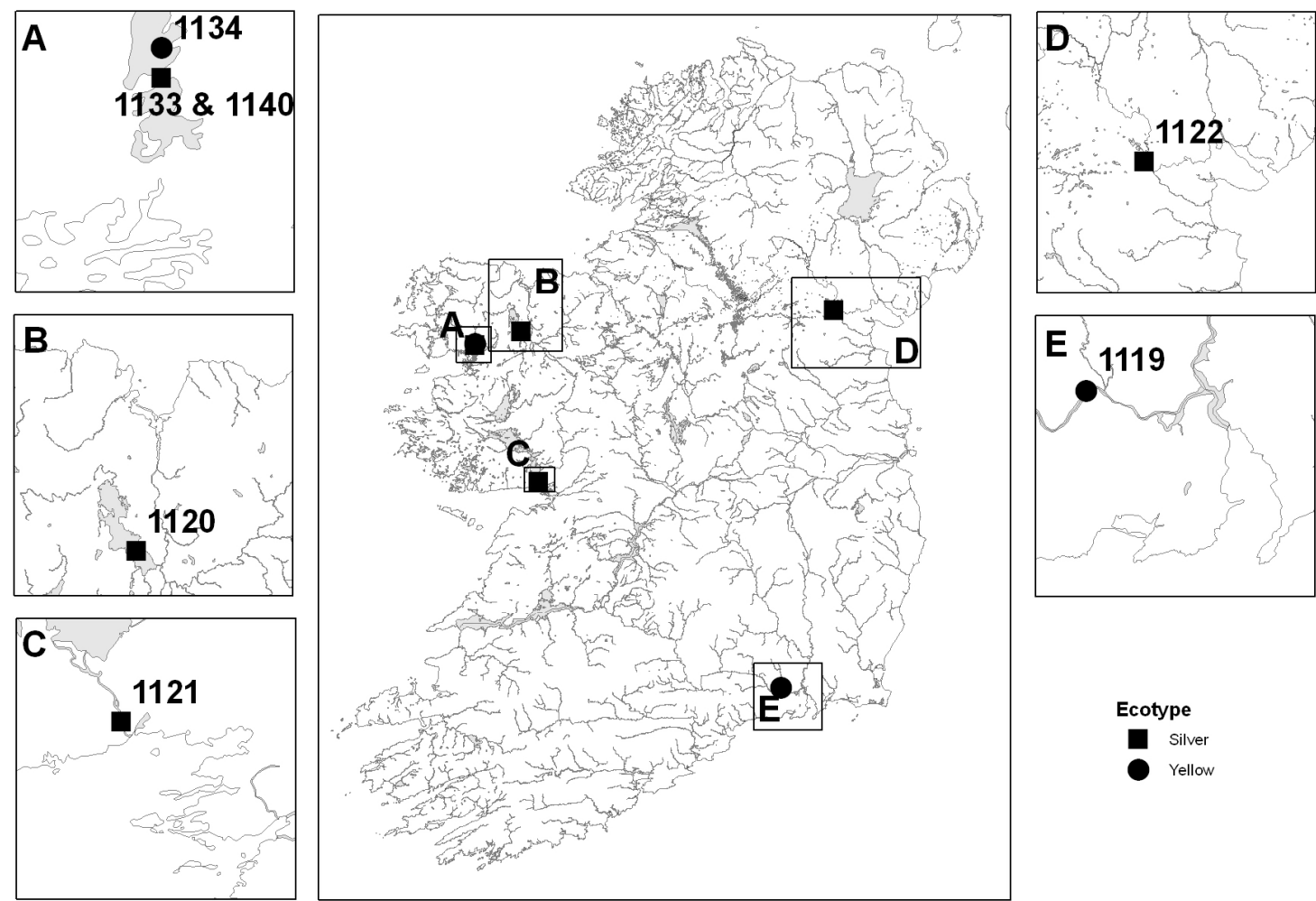

18

19

20

21

22

24

25

26

27

28 